\title{
Identification and Quantification of Paralytic Shellfish Toxins in Puget Sound Marine Organisms
}

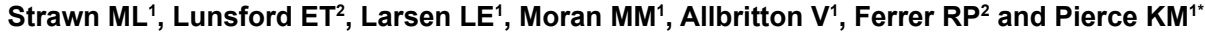 \\ ${ }^{1}$ Department of Chemistry and Biochemistry, Seattle Pacific University, Seattle, WA 98119, USA \\ ${ }^{2}$ Department of Biology, Seattle Pacific University, Seattle, WA 98119, USA
}

\begin{abstract}
Saxitoxin and its structural analog neosaxitoxin were identified and quantified in mussels and sea stars that were collected from the Puget Sound region during harmful algal blooms. The analysis was based on high performance liquid chromatography with fluorescence detection and pre-column oxidation. Quantitative analytical results revealed that saxitoxin and neosaxitoxin were present in some of the Puget Sound samples well above toxic levels (up to $265 \mu \mathrm{g}$ saxitoxin/100 g tissue and $111 \mu \mathrm{g}$ neosaxitoxin/100 g tissue). For all of the samples of interest, paralytic shellfish toxins other than saxitoxin and neosaxitoxin were semi-quantified and a total toxicity value was estimated for each sample. The samples ranged from nontoxic to very toxic (up to $3687 \mu \mathrm{g}$ saxitoxin-equivalents/100 $\mathrm{g}$ tissue).
\end{abstract}

Keywords: Saxitoxin; Neosaxitoxin; Paralytic shellfish toxins; High performance liquid chromatography

Abbreviations: B-1: gonyautoxin-5; C-1,2: C-toxins-1 and -2; dcGTX-2,3: decarbamoyl gonyautoxins-2 and -3 ; dcSTX: decarbamoyl saxitoxin; DOH: Department of Health; FDA: Food and Drug Administration; GTX-1,4: gonyautoxins-1 and -4; GTX2,3: gonyautoxins-2 and -3; HPLC-FLD: High Performance Liquid Chromatography with Fluorescence Detection; LOD: Limit of Detection; LOQ: Limit of Quantification; NEO: Neosaxitoxin; PST: Paralytic Shellfish Toxins; RSD: Relative Standard Deviation; SPE: Solid Phase Extraction; SD: Standard Deviation; STX: Saxitoxin; TEF: Toxicity Equivalence Factor; WCX: Weak Cation Exchange

\section{Introduction}

Saxitoxin (STX) and its structural analogues, collectively referred to as paralytic shellfish toxins (PST), are water soluble alkaloid neurotoxins that are naturally produced by microscopic algae like dinoflagellates. Shellfish such as mussels, clams, and other bivalve mollusks are filterfeeding organisms that tend to naturally accumulate (and sometimes metabolize) the toxins produced by the algae [1]. The state Department of Health (DOH) monitors algal bloom activity around the Puget Sound and frequently publishes the toxicity levels of shellfish at each beach so people can avoid harvesting toxic shellfish. The DOH uses a mouse bioassay to quantify the toxicity of shellfish [2]. The mouse bioassay involves injecting mice with an extract of shellfish flesh. The observed time until death correlates with estimated total PST concentration in shellfish flesh. The DOH closes fisheries when this bioassay reveals that total PST concentrations are greater than a certain toxic limit. The United States Food and Drug Administration (FDA) reports that total toxicity values greater than approximately $80 \mu \mathrm{g}$ STX-equivalents/100 $\mathrm{g}$ shellfish tissue are considered toxic and require regulatory action [1]. Values that are less than $38 \mu \mathrm{g}$ STX-equivalents/100 g shellfish tissue are considered nontoxic or not detectable.

The primary objective of this study was to use an instrumental method to identify and quantify PST toxins in mussels and sea stars from the Puget Sound region. We were interested in whether or not we could detect trophic transfer of PST toxins from prey to predator. Once we quantified the PST toxins in mussels and sea stars, we converted the toxin quantities into estimated total toxicity values with units that were the same as the units for mouse bioassay values. In some cases, $\mathrm{DOH}$ bioassay results for shellfish gathered during the same time period near the same location were available, so we compared our estimated total toxicity values to the $\mathrm{DOH}$ values. Thus, the secondary objective of this study was to compare the instrumental results to mouse bioassay results reported by the $\mathrm{DOH}$ for mussels that were collected at a similar time and location.

The instrumental method that we used for quantifying PST in marine organism tissues involved pre-column oxidation and high performance liquid chromatography with fluorescence detection (HPLC-FLD). We specifically analyzed the toxin content of Mytilus edulis mussel tissue and Pisaster ochraceus sea star tissue because people in the Puget Sound region commonly consume $M$. edulis and, likewise, $P$. ochraceus preys particularly upon $M$. edulis. Sea stars are a keystone species and the potential effects of PST toxins on sea stars is of interest to biologists or food and health scientists [3]. In fact, marine food scientists reported PST toxins in Astropectin scoparius, a type of sea star found in Taiwan [4]. We relied heavily on a published HPLC-FLD standard method of analysis for PST toxins in shellfish flesh [5]. Many other researchers have used that same published standard procedure for analyzing shellfish [6,7]. Still other researchers have quantified PST toxins in shellfish using uniquely modified versions of the published standard procedure [8-15]. These authors' alterations include changes to the solid phase extraction (SPE) sample processing steps [13], and changes to the oxidation steps $[12,14,15]$. We made slight modifications to the published standard procedure which are described in the Materials and Methods section herein. The modifications included using different SPE and sample preparation supplies, and the method was extended to dissect and analyze sea star organs. We used standards, spiked blank matrix, blank samples, and control samples to evaluate the method with our slight modifications.

In general, PST toxins have three-ring structures with four variable $\mathrm{R}$ groups as shown in Figure 1. The toxins are listed in Table 1. These can be categorized as non-R1-hydroxylated PST toxins or R1-hydroxylated PST toxins. The non-R1-hydroxylated toxins that we attempted to quantify included saxitoxin (STX), gonyautoxins-2 and -3 (GTX-2,3), gonyautoxin-5 (B-1), C-toxins-1 and -2 (C-1,2), decarbamoyl saxitoxin (dcSTX), and decarbamoyl gonyautoxins-2

*Corresponding author: Pierce KM, Department of Chemistry and Biochemistry, Seattle Pacific University, 3307 Third Avenue West, Suite 205, Seattle, WA 98119, USA, Tel: 206281 2102; E-mail: piercek@spu.edu

Received July 07, 2015; Accepted July 10, 2015; Published July 12, 2015

Citation: Strawn ML, Lunsford ET, Larsen LE, Moran MM, Allbritton V, et al. (2015) Identification and Quantification of Paralytic Shellfish Toxins in Puget Sound Marine Organisms. J Environ Anal Chem 2: 148. doi:10.4172/2380-2391.1000148

Copyright: (c) 2015 Strawn ML, et al. This is an open-access article distributed under the terms of the Creative Commons Attribution License, which permits unrestricted use, distribution, and reproduction in any medium, provided the original author and source are credited. 


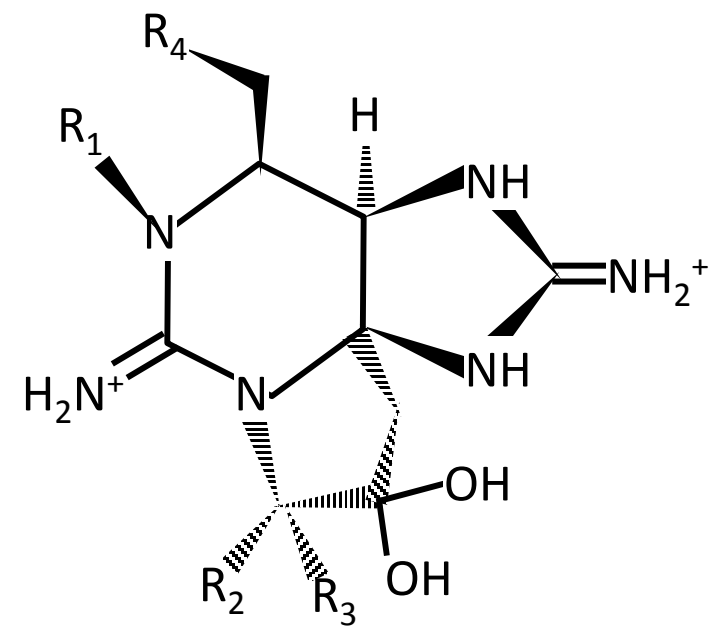

Figure 1: General structure of PST toxins. Solid lines are bonds in the plane of the page, dashed wedges are below the plane, and solid wedges are above the plane.

\begin{tabular}{|c|c|c|c|c|c|}
\hline $\mathrm{R}_{1}$ & $\mathrm{R}_{2}$ & $\mathrm{R}_{3}$ & $\mathrm{R}_{4}: \mathrm{NH}_{2} \mathrm{CO}_{2}$ & $\mathrm{R}_{4}: \mathrm{SO}_{3} \mathrm{NHCO}_{2}$ & $\mathrm{R}_{4:} \mathrm{OH}$ \\
\hline $\mathrm{H}$ & $\mathrm{H}$ & $\mathrm{H}$ & STX & GTX-5 (B-1) & dcSTX \\
\hline $\mathrm{OH}$ & $\mathrm{H}$ & $\mathrm{H}$ & NEO & GTX-6 (B-2) & dcNEO \\
\hline $\mathrm{OH}$ & $\mathrm{OSO}_{3}^{-}$ & $\mathrm{H}$ & GTX-1 & $C-3$ & dcGTX-1 \\
\hline $\mathrm{H}$ & $\mathrm{OSO}_{3}^{-}$ & $\mathrm{H}$ & GTX-2 & C-1 & dcGTX-2 \\
\hline $\mathrm{H}$ & $\mathrm{H}$ & $\mathrm{OSO}_{3}^{-}$ & GTX-3 & C-2 & dcGTX-3 \\
\hline $\mathrm{OH}$ & $\mathrm{H}$ & $\mathrm{OSO}_{3}^{-}$ & GTX-4 & C-4 & dcGTX-4 \\
\hline
\end{tabular}

Table 1: Symbols and substituents (R-groups) of PST toxins

and -3 (dcGTX-2,3). The R-1 hydroxylated toxins that we analyzed included neosaxitoxin (NEO) and gonyautoxins-1 and -4 (GTX-1,4). The previously published method of analysis recommended different oxidation procedures for these two categories of PST toxins (non-R1hydroxylated or R1-hydroxylated) [5].

\section{Materials and Methods}

The analytical method was related to a published standard method [5], but it also differed at various points, so it is important to describe the detailed method that was used herein.

\section{Standards}

Standard stock solutions of individual PST toxins (STX, dcSTX, B-1, and NEO) and standard stock solutions of mixed PST toxins (GTX-1,4, GTX-2,3, dcGTX-2,3, and C-1,2) were purchased from a vendor (National Research Council of Canada, 1200 Montreal Road, Ottawa, Ontario K1A 0R6, Canada). Some toxins were so physically similar and chromatographically inseparable that we were unable to resolve some pairs, so the standards for those toxins were purchased as a mixture of two toxins, hence the unresolved toxins are designated by a single symbol with two numerals (e.g. GTX-1,4 or dcGTX-2,3).

\section{Samples of marine organism tissues}

M. edulis and P. ochraceus organisms were obtained from Puget Sound beaches (under Washington Department of Fish and Wildlife permit \#13-249) during harmful algal blooms and between blooms. These time periods and daily mouse bioassay results were made available to the public by $\mathrm{DOH}$. Whole mussels were stored in plastic bags at $-80^{\circ} \mathrm{C}$. Sea stars were dissected to isolate the viscera and gonads and these organs were stored separately in polypropylene containers at $-80^{\circ} \mathrm{C}$. All samples were kept frozen until ready for homogenization and the following steps in the sample preparation process.

\section{Extract PST and prepare standards}

Using non-glass supplies, we mixed $5.00 \pm 0.10 \mathrm{~g}$ of homogenized tissue with $3.0 \mathrm{~mL}$ of $1 \%(\mathrm{v} / \mathrm{v})$ aqueous acetic acid in a hot bath and centrifuged to obtain the solvent extract containing PST. This was repeated and the solvent extracts were combined. If calibration standards were being prepared, then this was the point at which variable volumes of standard PST stock solution from the vendor were added to the extract of toxin-free shellfish matrix. The next step for all samples (unknown samples of interest and standards) was to dilute the extract to exactly $10.0 \mathrm{~mL}$ with nanopure water and this was labelled "crude extract". (Please note, an exception to this part of the procedure was necessary for the Silverdale sea stars' gonads; we were only able to acquire $3.2383 \mathrm{~g}$ and $0.3455 \mathrm{~g}$ of gonad tissue from two of the sea stars).

Next, a $3 \mathrm{~mL}$ Supelclean LC-18 SPE cartridge with $500 \mathrm{mg}$ sorbent (Sigma-Aldrich, PO Box 14508, St. Louis, Missouri, 63178, USA) was conditioned with $6 \mathrm{~mL}$ HPLC grade methanol followed by $6 \mathrm{~mL}$ nanopure water. Then $1.00 \mathrm{~mL}$ of crude extract ( $0.5 \mathrm{~g}$ tissue equivalent) was passed through the conditioned LC-18 cartridge and the effluent was collected. The LC-18 cartridge was washed with $2 \mathrm{~mL}$ water and this wash was combined with the effluent. The combined solution was diluted to $4.0 \mathrm{~mL}$ with water and it was labelled "SPE LC-18 effluent".

Next, a $3 \mathrm{~mL}$ Supra-Clean weak cation exchange (WCX) SPE cartridge with $500 \mathrm{mg}$ sorbent (Perkin Elmer, 940 Winter St., Waltham, Massachusetts 02451, USA) was conditioned with $10 \mathrm{~mL}$ of $0.01 \mathrm{M}$ ammonium acetate solution. Then $2.00 \mathrm{~mL}$ of SPE LC-18 effluent $(0.25$ $\mathrm{g}$ tissue equivalent) was passed through the cartridge and the effluent was collected into a plastic $15 \mathrm{~mL}$ graduated tube labelled "Fraction 1." The WCX cartridge was washed with $4.0 \mathrm{~mL}$ water, the wash was combined with the first effluent in the tube labelled "Fraction 1", it was diluted to a final volume of $6.0 \mathrm{~mL}$ with nanopure water. According to the literature, Fraction 1 potentially contained C-1,2 and C-3,4. The original published method used an SPE-COOH cartridge, but that item was unavailable to us, so we used WCX cartridges and we confirmed with standards and matching relative retention times with the literature that this cartridge worked similarly to the SPE-COOH cartridge for our application [5].

Next, $4.0 \mathrm{~mL}$ of $0.05 \mathrm{M} \mathrm{NaCl}$ solution was passed through the WCX cartridge, collected into a $15 \mathrm{~mL}$ plastic graduated tube labelled "Fraction 2," and diluted to a final volume of $4.0 \mathrm{~mL}$ with nanopure water. According to the literature, Fraction 2 potentially contained GTX-1,4, GTX-2,3, B-1, B-2, and dcGTX-2,3.

Next, $5.0 \mathrm{~mL}$ of $0.3 \mathrm{M} \mathrm{NaCl}$ solution was passed through the WCX cartridge, collected into a $15 \mathrm{~mL}$ plastic graduated tube labelled "Fraction 3," and diluted to a final volume of $5.0 \mathrm{~mL}$ with nanopure water. According to the literature, Fraction 3 potentially contained STX, NEO, and dcSTX. The original published method called for the solutions to be passed through the cartridges at specific constant flow rates, indicating an automated system was used for SPE steps. We did not have access to an automated SPE system, so all solutions were manually passed through SPE cartridges.

Using autopipets with disposable plastic tips, $100 \mu \mathrm{L}$ of SPE LC-18 
effluent was mixed with $25 \mu \mathrm{L}$ of $10 \%$ (w/v) aqueous $\mathrm{H}_{2} \mathrm{O}_{2}$ and 250 $\mu \mathrm{L}$ of $1 \mathrm{M} \mathrm{NaOH}$ in a $1.5 \mathrm{~mL}$ microcentrifuge tube. The solution was allowed to react at room temperature for 2.0 minutes, and then $20 \mu \mathrm{L}$ of concentrated acetic acid was added and mixed. The mixture was allowed to equilibrate at room temperature for 15 minutes and then it was injected into the HPLC. This chromatographic data was used to quantify the non-R1-hydroxylated PST toxins (STX, dcSTX, GTX-2,3, dcGTX-2,3, B-1, and C-1,2).

Using autopipets with disposable plastic tips, $100 \mu \mathrm{L}$ of Fraction 1,2 , or 3 extract was mixed with $100 \mu \mathrm{L}$ of "matrix modifier" and $500 \mu \mathrm{L}$ of "periodate oxidant" in a $1.5 \mathrm{~mL}$ microcentrifuge tube. The solution was allowed to react at room temperature for 1.0 minute, and then $5 \mu \mathrm{L}$ of concentrated acetic acid was added and mixed. The mixture equilibrated at room temperature for 15 minutes and then it was injected into the HPLC. Chromatograms for Fraction 2 were used to quantify GTX-1,4 and chromatograms for Fraction 3 were used to quantify NEO.

GTX-2,3 was detectable by both the peroxide and periodate oxidation methods, so we used the chromatogram from the oxidation method that produced the greatest response factor to quantify GTX2,3 , and we used the chromatogram from the other oxidation method to qualitatively confirm that a peak for GTX-2,3 was indeed present.

The "matrix modifier" that was mentioned earlier was a solution prepared by submitting PST-free oysters to the procedure that produced crude extract; then this "PST-free oyster crude extract" was used to obtain the "SPE LC-18 effluent" using the steps described above. Then this SPE LC-18 effluent was adjusted to pH 6.5 with $0.2 \mathrm{M} \mathrm{NaOH}$ and allowed to equilibrate until a precipitate formed; the supernatant was filtered through a $0.45 \mu \mathrm{m}$ filter, it was labelled "matrix modifier," and it was stored at $4^{\circ} \mathrm{C}$. The initial "PST-free oyster crude extract" was stored frozen for up 2 months at $-20^{\circ} \mathrm{C}$, and the matrix modifier was prepared from it every 2 weeks.

The "periodate oxidant" that was mentioned earlier was a solution prepared each day by mixing $5 \mathrm{~mL}$ of $0.03 \mathrm{M}$ periodic acid (stored at $4^{\circ} \mathrm{C}$ ), with $5 \mathrm{~mL}$ of $0.3 \mathrm{M}$ ammonium formate, and with $5 \mathrm{~mL}$ of $0.3 \mathrm{M}$ $\mathrm{Na}_{2} \mathrm{HPO}_{4}$ and adjusting the $\mathrm{pH}$ to 8.2 with $0.2 \mathrm{M} \mathrm{NaOH}$.

\section{Chromatography}

The HPLC was a Hewlett Packard 1100 series system with an Agilent 1260 Fluorescence Detector equipped with a Supelcosil LC-18DB column $(15 \mathrm{~cm} \times 4.6 \mathrm{~mm}, 5 \mu \mathrm{m}$ from Supelco, Bellefonte, PA $)$ and a $50 \mu \mathrm{L}$ sample loop. Mobile phase $\mathrm{A}$ was $0.1 \mathrm{M}$ aqueous ammonium formate and mobile phase $\mathrm{B}$ was $0.1 \mathrm{M}$ aqueous ammonium formate in $5 \%(\mathrm{v} / \mathrm{v})$ acetonitrile, both adjusted to $\mathrm{pH} 6$ using $0.1 \mathrm{M}$ acetic acid. The flow rate was $2 \mathrm{~mL} /$ minute and the mobile phase gradient was the following: linearly adjust from $0 \%$ to $5 \%$ mobile phase B in the first 5 minutes, then adjust from $5 \%$ to $70 \%$ mobile phase B for the next 4 minutes, then adjust from $70 \%$ down to $0 \% \mathrm{~B}$ for the next 2 minutes, and then hold at $0 \% \mathrm{~B}$ for 3 minutes. The excitation wavelength was 340 $\mathrm{nm}$, and the emission wavelength was $395 \mathrm{~nm}$. The HPLC instrument software was OpenLAB CDS ChemStation Edition Rev C.01.04 (Agilent Technologies, Santa Clara, CA, USA). The presence or absence of each toxin in each sample was determined by using the optimized automatic peak integration tool from the ChemStation software and manually matching retention times with the standards.

\section{Assumptions regarding unresolved toxins}

Throughout our analysis, we treated the mixtures of unresolved paired toxins as a single toxin. We assumed the paired toxins had equal response factors at the detector and we assumed their signals were simply additive and proportional to concentration within the limits of the standards' calibration curves. Later, when we mathematically converted observed toxin concentrations into total toxicity values, we found the toxicity equivalence factor for each toxin from the literature and we decided to use the average value for each pair of unresolved toxins [5,11]. This forced us to assume that a 1:1 mixture of the unresolved toxins represented each chromatographic peak. These assumptions were undoubtedly a source of error, but the assumptions were accepted in order to estimate the total toxicity of the samples of interest.

\section{Standard and sample replicates}

Each PST calibration model was developed using five to eight different standard concentrations, each prepared in a blank sample matrix and run in replicate three to four times. Well over a dozen mussels from each location and time period were pooled into multiple samples and homogenized. The pooled mussel samples were processed and analyzed in replicate three to five times. Results for multiple mussel samples from the same location and same time period were averaged and reported as a single quantity of amount of each PST present in mussel tissue from each location and time period. In some cases we were able to acquire three or four sea stars from the same location and time period, and these toxin concentrations were averaged to yield a single value reported for the sea star tissue at each site.

\section{Procedures for qualitative analysis}

Blank samples were analyzed with and without oxidation to identify matrix peaks versus PST peaks in the chromatograms. Relative retention times from literature sources were also used to verify peak identities. The matrix modifier was analyzed by the periodate and peroxide oxidation procedures to inspect its chromatograms and ensure the absence of toxins before it was used to prepare samples. The $50 \mu \mathrm{L}$ sample loop was washed with solvents between injections, washed with sample before injection, and the loop was completely filled with sample for each injection. Blank sample chromatograms were collected between runs to detect and avoid any cross contamination. Sea star and mussel control samples were collected during time periods when the $\mathrm{DOH}$ reported the beaches were free of toxins.

\section{Results and Discussion}

The calibration standards were used to determine the average retention time $\left(t_{\mathrm{R}}\right)$ with standard deviation (SD) for each toxin, listed in Table 2. Compared to all of the toxins, the $t_{\mathrm{R}}$ for GTX-2,3 varied the most at $7.85 \pm 0.34 \mathrm{~min}$ (average $t_{\mathrm{R}} \pm 1 \mathrm{SD}$ ). The other toxins had smaller SD that ranged from 0.05 to $0.29 \mathrm{~min}$. GTX-2,3 eluted around the time that the mobile phase composition was quite rapidly changing, so uncontrollable injector, pump, and pressure variations might have been the cause of the $t_{\mathrm{R}}$ variations. Table 2 also shows the toxicity equivalence factor (TEF) for each toxin relative to STX. For example, the TEF value for NEO is 0.92 , so NEO is $92 \%$ as toxic as STX. The remaining six toxins were less toxic than NEO. The TEF values were obtained from literature sources $[5,11]$.

Calibration data for the standard PST samples are also listed in Table 2. Some of the calibration models had better figures of merit than others in terms of limit of detection (LOD), limit of quantification (LOQ), linearity of the calibration model $\left(\mathrm{R}^{2}\right)$, and the standard deviation of peak areas $\left(\mathrm{SD}_{\mathrm{y}}\right)$. Some of the toxins provided larger response factors at the detector than other toxins, and some of the toxins had less interference with observed or unobserved coelutants. 
Citation: Strawn ML, Lunsford ET, Larsen LE, Moran MM, Allbritton V, et al. (2015) Identification and Quantification of Paralytic Shellfish Toxins in Puget Sound Marine Organisms. J Environ Anal Chem 2: 148. doi:10.4172/2380-2391.1000148

Page 4 of 6

\begin{tabular}{|c|c|c|c|c|c|c|c|c|c|}
\hline PST & TEF & $\begin{array}{c}\text { Quantitative } \\
\text { Oxidation Method }\end{array}$ & $\begin{array}{l}\text { Average } t_{R} \pm 1 S_{\text {tR }} \\
\quad \text { (minutes) }\end{array}$ & $\begin{array}{c}\text { Standard } \\
\text { Concentrations } \\
\text { ( } \mu \mathrm{g} \text { PST/100 g tissue) }\end{array}$ & $\begin{array}{c}\text { Calibration } \\
\text { Model }\end{array}$ & $\mathbf{R}^{2}$ & $S D_{y}$ & $\begin{array}{l}\text { LOD } \\
\text { ( } \mu \mathrm{g} \text { PST/ } 100 \mathrm{~g} \\
\text { tissue) }\end{array}$ & $\begin{array}{c}\text { LOQ } \\
\begin{array}{l}\mu \mathrm{g} \mathrm{PST} / 100 \mathrm{~g} \\
\text { tissue) }\end{array}\end{array}$ \\
\hline STX & 1.00 & Peroxide & $10.3 \pm 0.3$ & 39 to 196 & $y=0.263 x-2.19$ & 0.97 & 0.08 & 0.9 & 3.1 \\
\hline NEO & 0.92 & Periodate, Fraction 3 & $6.5 \pm 0.1$ & 62 to 209 & $y=0.027 x-1.19$ & 0.97 & 0.05 & 5.7 & 18.9 \\
\hline GTX-1,4 & 0.86 & Periodate, Fraction 2 & $2.9 \pm 0.1$ & 98 to 333 & $y=0.0013 x-0.01$ & 0.99 & 0.02 & 43.8 & 146.2 \\
\hline dcSTX & 0.51 & Peroxide & $5.0 \pm 0.1$ & 34 to 168 & $y=0.509 x-4.41$ & 0.97 & 2.29 & 13.5 & 45.0 \\
\hline GTX-2,3 & 0.50 & Peroxide & $7.9 \pm 0.3$ & 95 to 622 & $y=0.098 x+4.01$ & 0.90 & 1.13 & 34.5 & 115.0 \\
\hline dcGTX-2,3 & 0.27 & Peroxide & $2.8 \pm 0.3$ & 91 to 500 & $y=0.047 x+1.88$ & 0.87 & 0.14 & 9.0 & 30.0 \\
\hline B-1 & 0.06 & Peroxide & $8.6 \pm 0.1$ & 32 to 106 & $y=0.108 x-2.05$ & 0.91 & 0.40 & 11.2 & 37.3 \\
\hline$C-1,2$ & 0.05 & Peroxide & $4.5 \pm 0.1$ & 105 to 359 & $y=0.032 x+0.37$ & 0.80 & 0.29 & 26.9 & 89.7 \\
\hline
\end{tabular}

Table 2: Information for standard samples of PST toxins, including toxicity equivalence factor (TEF), quantitative oxidation method, average retention time $\left(t_{\mathrm{R}}\right)$ with standard deviation $\left(S D_{1}\right)$, least-squares best-fit calibration model coefficients $(y=m x+b)$, calibration model squared correlation coefficient $\left(R^{2}\right)$ for the indicated range of standard concentrations, standard deviation of peak areas for the least concentrated standard $\left(\mathrm{SD}_{\mathrm{y}}\right)$, limit of detection $(\mathrm{LOD} \equiv 3 \mathrm{SD} / \mathrm{m})$, and limit of quantification $(\mathrm{LOQ} \equiv 10 \mathrm{SD} / \mathrm{m})$.

We were interested in estimating a total toxicity value for each sample relative to STX (akin to estimating a mouse bioassay value), so it was useful that the calibration models for the toxins that were most toxic (STX and NEO) had good figures of merit. Relative to all eight toxins that were calibrated, the STX and NEO models had high $\mathrm{R}^{2}$ values, good resolution from neighboring peaks or background contributions, and low $\mathrm{SD}_{\mathrm{y}}$, resulting in acceptable $\mathrm{LOD}$ and LOQ values. Contrarily, the GTX-2,3 model had the poorest combination of both a large LOD and a somewhat low $\mathrm{R}^{2}$ value. Indeed, it will be shown later that for some of the samples of interest, the GTX-2,3 calibration model predicted negative concentration values for that PST. In summary, the figures of merit in Table 2 show that our calibration models for GTX-1,4, dcSTX, GTX-2,3, dcGTX-2,3, B-1, C-1,2, and GTX-2,3 were less reliable than our calibration models for STX and NEO. To be clear, other researchers have achieved better success at calibrating the PST toxins [5], but due to budget and sample limitations, we were unable to further investigate improvements to the calibration models. We considered reporting only the predicted concentrations for STX and NEO, however, we decided to report the application of all eight calibration models for all eight toxins with the caveat that the values are estimates.

The predicted concentrations of all eight toxins for each averaged pooled sample from each location and time period of interest are reported in Table 3. The average relative standard deviation (\%RSD) for predicted concentrations of STX was $\pm 15 \%$ RSD and for NEO it was $\pm 5 \%$ RSD. As an example, the chromatogram in (Figure 2) shows that the SPE LC-18 effluent from Port Ludlow mussels collected during a period of "high bloom intensity" (08/28/2012) appeared to contain signals from non-R1-hydroxylated PST toxins, including STX.

Overall, eighteen pooled samples of interest from various locations and time periods were analyzed and described in Table 3 in reverse chronological order of the date of sample collection. To be clear, (Table 3) summarizes the main significance of this work: the documentation of unique environmental samples of interest that were gathered during and between harmful algal blooms in the Puget Sound region. To cite an example from Table 3, analysis revealed that mussels that were collected from the Silverdale beach site in July 2014 contained an average of $21 \mu \mathrm{g}$ STX/100 g tissue, $97 \mu \mathrm{g}$ GTX-2,3/100 g tissue, $32 \mu \mathrm{g}$ $\mathrm{B}-1 / 100 \mathrm{~g}$ tissue, and $48 \mu \mathrm{g}$ C-1,2/100 g tissue (3 samples of multiple pooled mussels from the site were each processed 4 times, yielding 12 replicates that were averaged to provide these results). The other four toxins were absent in this sample. No other reports exist for quantities of STX and NEO in these specific samples from these locations and time periods, however, it can be said that these STX and NEO quantities are similar to the quantities observed for naturally contaminated samples (from 2005 and earlier) that were reported in the literature [5].

As shown in Table 2, NEO was quantified using the chromatogram for the Fraction 3 solution after periodate oxidation, while dcSTX was quantified using the chromatogram for the SPE LC-18 solution after peroxide oxidation. Literature sources warned of interference between NEO and a co-eluting minor secondary dcSTX peak in Fraction 3 which appears after periodate oxidation dcSTX. According to the literature, this minor secondary dcSTX peak appeared in the chromatogram when dcSTX was present at concentrations greater than a particular threshold value. We tested this and confirmed that dcSTX standards prepared at concentrations below $322 \mu \mathrm{g}$ dcSTX/100 $\mathrm{g}$ tissue yielded zero signal (peak was absent) in the chromatograms for Fraction 3. Assuming the dcSTX quantities in Table 3 are correct, none of the samples of interest contained dcSTX above the threshold, so we assumed the NEO peak area did not contain contributions from dcSTX and we assumed the NEO calibration model was indeed applicable to all of the samples of interest.

If the reader compares Tables 2 and 3 , it reveals another assumption that we made. We assumed the calibration models applied to the entire range of PST concentrations in the unknown mussel and sea star samples, even though many of the unknown observed PST signals were outside the range of the standards that were actually prepared and tested for linearity. This limitation was partly due to the maximum concentrations of standard solutions that were offered by the vendor. It is possible that additional standard sample preparation steps such as preconcentation and solvent reduction procedures would improve the applicable range of the calibration models.

In Table 3, we report the total toxicity that was estimated for each sample by assuming the quantitative predictions for all eight toxins were accurate. The total toxicity was defined as the sum of the concentration of each detected PST multiplied by its TEF. For example, the Silverdale mussels collected in July 2014 had a total toxicity value equal to $1.00(21 \mu \mathrm{g} \mathrm{STX} / 100 \mathrm{~g}$ tissue $)+0.50(97 \mu \mathrm{g}$ GTX-2,3/100 g tissue $)+0.06(32 \mu \mathrm{g} \mathrm{B}-1 / 100 \mathrm{~g}$ tissue $)+0.05(48 \mu \mathrm{g}$ C-1,2/100 g tissue $)$ $=74 \mu \mathrm{g}$ STX-equivalents $/ 100 \mathrm{~g}$ tissue. The replicate analyses of three different sea stars from the same location and time period were pooled and averaged, which revealed that the Silverdale sea star viscera had a total toxicity of $6 \mu \mathrm{g}$ STX-equivalents/100 g tissue. We observed no quantifiable peaks in the chromatograms of the Silverdale sea stars' gonads and it is unknown if this was due to the absence of PST toxins, or if it was due to the PST toxins being present at a concentration that was lower than the LOD.

In general, the total toxicity values revealed that the two most toxic samples were the Kingston mussels and the Port Ludlow mussels that were collected during harmful algal blooms in the summer of 2012. When comparing sea stars to mussels that were collected at the same time and location (Kingston, Silverdale, and Burley), it was evident that the sea stars were always less toxic than the mussels. It is possible this 
Citation: Strawn ML, Lunsford ET, Larsen LE, Moran MM, Allbritton V, et al. (2015) Identification and Quantification of Paralytic Shellfish Toxins in Puget Sound Marine Organisms. J Environ Anal Chem 2: 148. doi:10.4172/2380-2391.1000148

Page 5 of 6

\begin{tabular}{|c|c|c|c|c|c|c|c|c|c|c|c|}
\hline \multirow[t]{2}{*}{ Date } & \multirow[t]{2}{*}{$\begin{array}{l}\text { Location of } \\
\text { Organisms }\end{array}$} & \multirow{2}{*}{$\begin{array}{c}\text { STX } \\
\text { Concentration } \\
(\mu \mathrm{g} \mathrm{STX} / 100 \mathrm{~g} \\
\text { tissue } \pm 1 \mathrm{SD})\end{array}$} & \multirow{2}{*}{$\begin{array}{c}\text { NEO } \\
\text { Concentration } \\
(\mu \mathrm{g} \mathrm{NEO} / 100 \mathrm{~g} \\
\text { tissue } \pm 1 \mathrm{SD})\end{array}$} & \multicolumn{6}{|c|}{$\begin{array}{l}\text { Estimated Concentration of Other PST } \\
\qquad(\mu \mathrm{g} \mathrm{PST} / 100 \mathrm{~g} \text { tissue })\end{array}$} & \multirow{2}{*}{$\begin{array}{c}\text { Estimated Total } \\
\text { Toxicity } \\
(\mu \mathrm{g} \text { STX- } \\
\text { equivalents/ } \\
100 \mathrm{~g} \text { tissue) }\end{array}$} & \multirow{2}{*}{$\begin{array}{c}\text { DOH Bioassay Value } \\
\text { for similar samples } \\
\text { ( } \mu \mathrm{g} \text { STX-equivalents/ } \\
100 \mathrm{~g} \text { tissue) }\end{array}$} \\
\hline & & & & GTX-1,4 & dcSTX & GTX-2,3 & dcGTX-2,3 & B-1 & $\mathrm{C}-1,2$ & & \\
\hline 9/25/2014 & Quilcene Bay Mussel & $14 \pm 1$ & 0 & 0 & 0 & 14 & 0 & 0 & 68 & 24 & Unknown \\
\hline 9/19/2014 & Penrose Point Mussel & 0 & 0 & 0 & 0 & 37 & 0 & 0 & 0 & 18 & Unknown \\
\hline $8 / 7 / 2014$ & Burley Mussel & $19 \pm 5$ & 0 & 0 & 0 & 120 & 0 & 0 & 0 & 79 & Unknown \\
\hline $8 / 7 / 2014$ & $\begin{array}{l}\text { Burely Sea Star } \\
\text { Viscera }\end{array}$ & $12 \pm 1$ & 0 & 74 & 0 & -13 & 0 & 0 & 2 & 69 & Unknown \\
\hline $8 / 7 / 2014$ & Alki Sea Star Viscera & $9 \pm 0.4$ & 0 & 0 & 0 & 0 & -16 & 0 & 27 & 7 & Unknown \\
\hline $7 / 10 / 2014$ & $\begin{array}{l}\text { Silverdale Sea Star } \\
\text { Viscera }\end{array}$ & $8 \pm 6$ & 0 & 0 & 0 & -11 & 0 & 18 & 47 & 6 & $\begin{array}{l}\text { Unknown; DOH } \\
\text { observed toxic } \\
\text { mussels }\end{array}$ \\
\hline $7 / 10 / 2014$ & $\begin{array}{l}\text { Silverdale Sea Star } \\
\text { Gonads }\end{array}$ & 0 & 0 & 0 & 0 & 0 & 0 & 0 & 0 & 0 & $\begin{array}{l}\text { Unknown, } \mathrm{DOH} \\
\text { observed toxic } \\
\text { mussels }\end{array}$ \\
\hline $7 / 9 / 2014$ & Silverdale Mussel & $21 \pm 2$ & 0 & 0 & 0 & 97 & 0 & 32 & 48 & 74 & $\begin{array}{l}\text { Unknown, } \mathrm{DOH} \\
\text { observed toxic } \\
\text { mussels }\end{array}$ \\
\hline $7 / 31 / 2013$ & Alki Sea Star Viscera & 0 & 0 & 0 & 0 & 0 & 0 & 0 & 0 & 0 & $\begin{array}{l}\text { Unknown, } \mathrm{DOH} \\
\text { observed nontoxic } \\
\text { mussels }\end{array}$ \\
\hline 9/7/2012 & $\begin{array}{l}\text { Kingston Sea Star } \\
\text { Viscera }\end{array}$ & $29 \pm 1$ & 0 & 0 & 19 & 1167 & 142 & 351 & 78 & 685 & $\begin{array}{l}\text { Unknown, } \mathrm{DOH} \\
\text { observed toxic } \\
\text { mussels }\end{array}$ \\
\hline 9/7/2012 & Kingston Mussel & $265 \pm 44$ & $111 \pm 8$ & 2578 & 43 & 2075 & 125 & 189 & 0 & 3687 & 2000 to 10000 \\
\hline $8 / 28 / 2012$ & Port Ludlow Mussel & $134 \pm 9$ & $93 \pm 5$ & 1166 & 20 & 747 & 46 & 92 & 0 & 1623 & 2000 to 3000 \\
\hline $8 / 2 / 2012$ & Alki Mussel & $20 \pm 2$ & $53 \pm 3$ & 491 & 0 & 151 & 144 & 69 & 0 & 610 & 0 to 38 \\
\hline $8 / 1 / 2012$ & Port Ludlow Mussel & $31 \pm 11$ & $50 \pm 3$ & 341 & 12 & 172 & 0 & 40 & 0 & 465 & $\sim 1000$ \\
\hline $7 / 20 / 2012$ & Everett Mussel & $12 \pm 0.2$ & 0 & 197 & 0 & 13 & 0 & 23 & 0 & 190 & 0 to 38 \\
\hline $7 / 18 / 2012$ & Dockton Mussel & $73 \pm 5$ & $52 \pm 2$ & 249 & 21 & 328 & -0.3 & 144 & 0 & 518 & $\sim 1000$ \\
\hline $7 / 17 / 2012$ & Alki Mussel & $25 \pm 2$ & $46 \pm 2$ & 224 & 13 & 122 & -29 & 48 & 0 & 323 & 100 to 200 \\
\hline $10 / 30 / 2011$ & Seacrest Mussel & $12 \pm 1$ & 0 & 0 & 0 & -30 & 0 & 0 & 0 & -3 & 0 to 38 \\
\hline
\end{tabular}

Table 3: Information for samples of interest gathered from Puget Sound region, including date sample was obtained, location of organism, tissue type, observed average STX concentration with standard deviation (SD), observed average NEO concentration with SD, estimated concentrations of the less toxic PST toxins, estimated total toxicity ( $\mu \mathrm{g}$ STX-equivalents $/ 100 \mathrm{~g}$ tissue), and average DOH mouse bioassay value ( $\mu \mathrm{g}$ STX-equivalents/100 $\mathrm{g}$ tissue) for similar samples that were gathered at the same location and same time period.

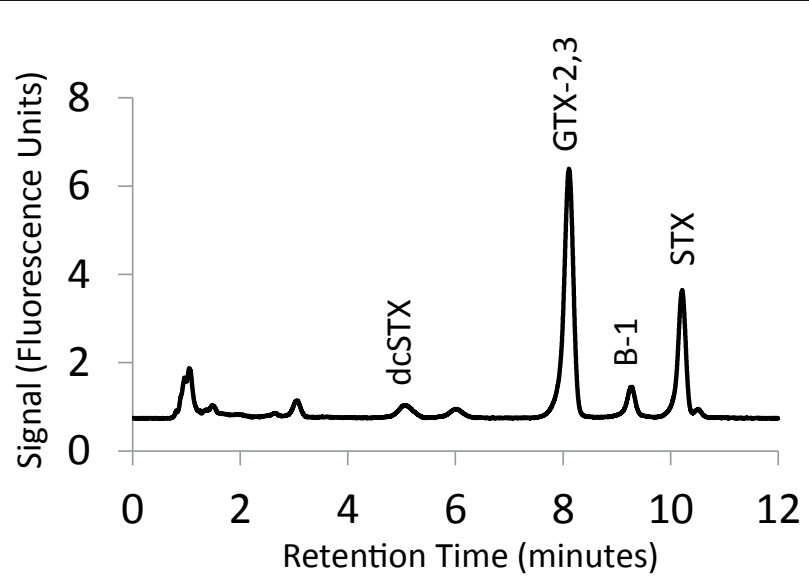

Figure 2: HPLC-FLD chromatogram of peroxide-oxidized SPE LC-18 effluent from Port Ludlow mussels contains signals that indicate the presence of nonR1-hydroxylated PST toxins.

was due to trophic transfer of PST from prey to predator.

Despite the uncertainty, the total toxicity estimation was useful because it produced a value that could be compared to the DOH mouse bioassay value. Some of our predicted values qualitatively agreed with values provided by the mouse bioassay, but some disagreed. For example, we predicted that the total toxicity for Kingston mussels was $3687 \mu \mathrm{g}$ STX-equivalents/100 g tissue, and this was within the range of values provided by the DOH (2000-10000 $\mu \mathrm{g}$ STX-equivalents/100 g tissue) for similar samples, as listed in Table 3 . The total toxicity value we observed for the Kingston Marina sea star was $685 \mu \mathrm{g}$ PST/100 g tissue, but no mouse bioassay value was available for comparison because the $\mathrm{DOH}$ does not monitor sea star toxicity.

Sea stars are not as prevalent in the human diet as mussels are, so it is reasonable for the $\mathrm{DOH}$ to forego monitoring sea star toxicity. However, some cultures do more commonly include sea stars in the diet, so quantification of PST toxins in sea stars is of interest [4]. Furthermore, the quantification of PST toxins in sea star tissue may be significant to biologists who study this keystone predator that preys on toxic mussels [3]. Further work would be necessary to determine whether sea star extracts contain unique co-elutants that require a different matrix-modifier solution than was used herein.

A case-3 paired t-test was performed to semi-quantitatively compare the HPLC-FLD method with the mouse bioassay for eight of the samples in Table 3 (we used the eight samples for which an average mouse bioassay value was available). If there was a significant difference between the results provided by the HPLC-FLD method and the mouse bioassay, then the calculated $t$-value $\left(t_{\text {calc }}\right)$ would be greater than the tabulated $\mathrm{t}$-value $\left(\mathrm{t}_{\text {table }}\right)$. The result was $\mathrm{t}_{\text {calc }}=1.29<\mathrm{t}_{\text {table }}=$ 2.37 (95\% confidence interval with 7 degrees of freedom). The t-test 
Citation: Strawn ML, Lunsford ET, Larsen LE, Moran MM, Allbritton V, et al. (2015) Identification and Quantification of Paralytic Shellfish Toxins in Puget Sound Marine Organisms. J Environ Anal Chem 2: 148. doi:10.4172/2380-2391.1000148

revealed that we could be tentatively confident that our HPLC-FLD method was capable of estimating toxicity values that were similar to mouse bioassay values, though a larger paired-sample size would foster more confidence. One advantage that was provided by the HPLC-FLD method, but not by the mouse bioassay, was the ability to be chemically selective and potentially reveal exactly which PST toxins were present in each sample.

\section{Conclusion}

In conclusion, STX and NEO were identified and quantified in mussels and sea stars that were collected from Puget Sound marinas during harmful algal blooms. The method of analysis was similar to a previously published HPLC-FLD method, but with slight modifications for sample preparation and analysis of sea star tissue. For all of the samples of interest, PST toxins other than STX and NEO were semiquantified. For all of the samples of interest, total toxicity values were estimated revealing that samples ranged from nontoxic to quite toxic. When both mussels and sea stars were gathered from the same location and time period, we observed that PST toxins were present at higher concentrations in the mussel tissue than in the sea star tissue. Trophic transfer of PST toxins from prey to predator is one potential explanation for that pattern.

\section{Acknowledgments}

Seattle Pacific University Department of Chemistry and Biochemistry, Seattle Pacific University Center for Scholarship and Faculty Development Faculty Research Grant, Seattle Pacific University Department of Biology, Montana Family Endowment, M. J. Murdock Trust Foundation.

\section{References}

1. AOAC (1990) Official Methods of Analysis, Mouse Bioassay, Ed. Hellrich, K. Association of Official Analytical Chemists, Arlington, VA

2. Ferrer RP, Lunsford ET, Candido CM, Strong ML, Pierce KM (2015) Saxitoxin and the ochre sea star: Molecule of keystone significance and a classic keystone species. Integr Comp Biol pii: icv010

3. Lin SJ, Tsai YH, Lin HP, Hwang DF (1998) Paralytic toxins in Taiwanese starfish Astropecten scoparius. Toxicon 36: 799-803.
4. Lawrence JF, Niedzwiadek B, Menard C (2005) Quantitative Determination of Paralytic Shellfish Poisoning Toxins in Shellfish Using Prechromatographic Oxidation and Liquid Chromatography with Fluorescence Detection: Collaborative Study. J AOAC Int 88: 1714-1732.

5. Lawrence JF, Wong B, Menard C (1996) Determination of Decarbamoyl Saxitoxin and its Analogues in Shellfish by Prechromatographic Oxidation and Liquid Chromatography with Fluorescence Detection. J AOAC Int 79: 1111 1115.

6. Ben-Gigirey B, Rodriguez-Velasco ML, Otero A, Vieites JM, Cabado AG (2012) A comparative study for PSP toxins quantification by using MBA and HPLC official methods in shellfish. Toxicon 60: 864-873.

7. Bates HA, Kostriken R, Rapoport H (1978) A Chemical Assay for Saxitoxin Improvements and Modifications. Journal of Agricultural and Food Chemistry 26: $252-254$.

8. Bates HA, Rapoport H (1975) A Chemical Assay for Saxitoxin, the Paralytic Shellfish Poison. Journal of Agricultural and Food Chemistry 23: 237-239.

9. Carreto JI, Carignan MO, Montoya NG (2001) Comparative studies on mycosporine-like amino acids, paralytic shellfish toxins and pigment profiles of the toxic dinoflagellates Alexandrium tamarense, A. catanella, and A. minutum. Marine Ecology Progress Series 223: 49-60.

10. Riet JMVD, Gibbs RS, Muggah FWCPM, Rourke WA, Burns G, et al. (2009) Liquid Chromatographic Post-Column Oxidation Method for Analysis of Paralytic Shellfish Toxins in Mussels, Clams, Scallops, and Oysters: SingleLaboratory Validation. J AOAC Int 92:1690-1704.

11. Turner AD, Hatfield RG, Rapkova M, Higman W, Algoet M, et al. (2011) Comparison of AOAC 2005.06 LC official method with other methodologies for the quantitation of paralytic shellfish poisoning toxins in UK shellfish species. Anal Bioanal Chem 399: 1257-1270.

12. Turner AD, Hatfield RG (2012) Refinement of AOAC Official Method 2005.06 liquid chromatography-fluorescence detection method to improve performance characteristics for the determination of paralytic shellfish toxins in king and queen scallops. J AOAC Int 95: 129-142.

13. Vale P, Rangel I, Silva B, Coelho P, Vilar A (2009) Atypical profiles of paralytic shellfish poisoning toxins in shellfish from Luanda and Mussolo bays, Angola. Toxicon 53: 176-183.

14. Vale P, Taleb H (2005) Assessment of quantitative determination of paralytic shellfish poisoning toxins by pre-column derivatization and elimination of interfering compounds by solid-phase extraction. Food Additives and Contaminants 22: 838-846.

15. Harris DC (2010) Quantitative Chemical Analysis. (8thedn), WH Freeman and Company, New York. 